\title{
Spatial Patterns of Public Facility Services based on Grid/Cell Supply Approach (Case Study: Elementary School in Malang, Surakarta \& Banjarmasin City)
}

\author{
Deni Agus Setyono ${ }^{1, *}$, Septiana Hariyani ${ }^{1}$, Denny Dwi Cahyono ${ }^{1}$, and Masdar Helmy ${ }^{1}$ \\ ${ }^{1}$ Urban and Regional Planning Department - Brawijaya University, MT. Haryono 167, Malang City, \\ Indonesia
}

\begin{abstract}
Public facilities have various types and functions to support people activities. Provision of public facilities in Indonesia is carried out on the base of population size and spatial approach, which for the development of new facilities used the scale and capacity of services analysis on related facility. This study aims to measures service rates of elementary school in the Malang, Surakarta and Banjarmasin City based on supply (school avalaibility) aspect, and then to identify spatial pattern of the services. As previous, the measurement was done with the administrative boundary as analysis units but then the grid/cell approach were used to obtain accurate results. Based on the analysis result, service capacity of elementary school in the Malang City defined by the mash/grid/cell approach was 271,75\% meanwhile in the Banjarmasin City was $535,68 \%$ and Surakarta City was $1.510,4 \%$. These results means that school in these three cities can meet the demand with more than $3-15$ times than existing population size. The results also illustrates that people in these three respective cities can access elementary school not only in their administrative boundary but also they access school everywhere of their city areas.
\end{abstract}

\section{Introduction}

The avalaibility of public facilities are quite important especially to enhance the urban growth and development. These urban facilities has functions that can support various activities that carried out by community. Hence provision of urban facilities adequately is necessary to improve the quality of city development and its community resources. One of the urban facilities that has important function is educational facilities which will be the

\footnotetext{
* Corresponding author: deni.setyono08@gmail.com
} 
focus on this research, particularly for elementary schools. Procurement education in adequate sufficient is necessary to increase the quality of human resources. These research focused to identify the elementary schools or facilities service because there are national agenda in education sector named "Wajib Belajar 9 Tahun" whereas all young peoples in Indonesia are obliged to obtain education services especially in the elementary and junior high school level. The government tried to provide elementary school in various areas yet sometimes not supported by adequate planning procedure. The planning process must consider the existing education services by the number and distribution of elementary school in order to analyze the level to access school.

In another discussion, public access to school quite different in various areas, especially between the urban and rural area or the centre and fringe areas because the provision of facilities were generally concentrated on the activity centers. Particularly in rural areas, it is often represented have low access to the elementary school. These research is advanced research phase that conducted in aims to determine accessibility conditions of education facility services. In the early phase of research, we conducted the suitable method that can interpreted the service rates and accessibility conditions especially for elementary school. Related with those previous study, the accessibility of elementary school will be identified and analyzed using the cellular/mash approach in this part. This research conducted with 3 cities as area study namely Malang City, Surakarta City and Banjarmasin City which are indicated had similar characteristics as medium - large cities in Indonesia. The determination of these cities are expected to get the comprehensive results related elementary school service patterns in urban areas. To the best author's knowledge, there is no research that conducted to get spatial pattern of facility services especially for educational facilities in developing countries like Indonesia.

To define which method has valuable result then Moran's I was used. In mash/cellular approach, the calculation of service area focused on the built-up areas. Therefore author through this research want to give the comprehensive description about urban facilities services pattern in aim to devise a provision method of urban facilities.

\section{Methods}

The research was conducted in three cities that derived from different provinces, namely Malang City (East Java Province), Surakarta City (Central Java Province) and Banjarmasin City (South Kalimantan Province). Those three city has similar characteristic thus considered as study area in this research, which are as medium city based on population size, known as education city and also similar administrative division. Malang City has an administrave area about $110 \mathrm{~km}^{2}$ and there are 851,298 inhabitants (BPS, 2016) live in this city. Malang City consist of 5 districts which are Blimbing, Kedungkandang, Klojen, Lowokwaru and Sukun District. Then, Surakarta City also known as Solo City also has similar characteristics with Malang City. The total city around $44 \mathrm{~km}^{2}$ and total population reached 512,226 inhabitants in 2015 (BPS, 2016). Administratively, Surakarta City area also divided into 5 districts i.a Laweyan, Serengan, Pasar Kliwon, Jebres and Banjarsari District. And lastly is Banjarmasin City, which has administrative area about $98 \mathrm{~km}^{2}$ and population size around 675,440 in 2015 (BPS, 2016). Banjarmasin City also divided by 5 districts, which are South Banjarmasin, East Banjarmasin, West Banjarmasin, Central 
Banjarmasin and North Banjarmasin District. Overview of these three cities can be seen as the following map.
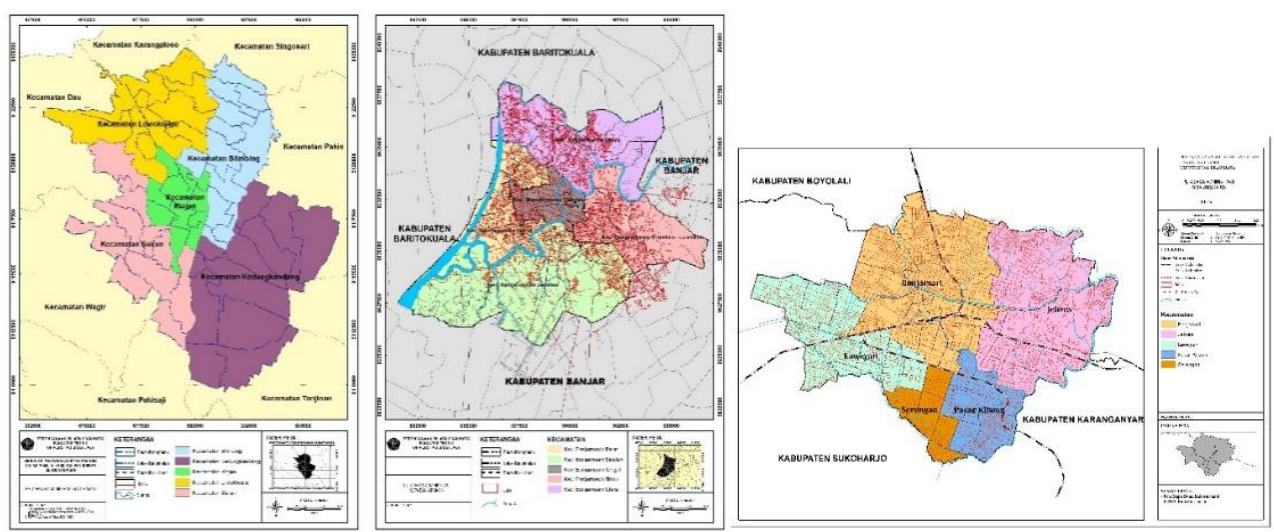

Fig. 1. Map of Administrative Area in Malang, Banjarmasin and Surakarta City.

Various educational facilities ranging from kindergarten until university are contained in these three city. Regarding the facility, the focus of this research aimed to elementary school as indicated relevance with national agenda on education sector "Wajib Belajar 9 Tahun". Development of elementary school quite important in order to meet the needs of educational services for all citizen and it is part of basic services on primary education development program. The provision of elementary facilities up to now based only form national standard with the main factor is population aspect and there is no emphasis with the local characteristics and conditions especially on spatial aspect.

Several procedures was used in this research. The first step was identification of school number and location in each city to get the existing spatial distribution characteristic. And another step was divide the city area using grid/cell/mash set with the cell size of $250 \times 250$ meter. Futhermore the range of services was identified using imaginary spheres with circular looking (layer) of each school location. And then assessment was carried out with overlay technique between service layers and grid/cell set layers as catchment process. Based on those process, it could be known how many school service layers that can be catched in each cell and then the total layer in every cell in each village boundary was calculated as mean value. These results can illustrates as average number of school that can serve or can be accessed by population and then the average number will determine the rate of elementary school service in each village. Moreover the result will be analyze using Moran's I to examine the links or relationship between area on spatial views. Based on author's knowledge, Moran's I analysis used to calculate spatial bounds, find a spatial model, etc. In this research, the authors tried Moran's I analysis as a method to compare spatial pattern of elementary school services. 


\section{Result and discussions}

\subsection{Spatial distribution of elementary school by existing units}

This is early stage of the research, which is define the elementary school service rates based on the population size and existing number of school units that only located in each subdistrict or village boundaries. The spatial distribution of school can determine rate of service and shortages of facility in each city. Based on the data, Malang City has the highest number of elementary school which is 323 unit meanwhile Banjarmasin and Surakarta City has $252 \& 275$ unit. As further described, Kedungkandang District has the highest number of elementary school in Malang City reached 79 unit. While Banjarsari District has the most number of elementary school in Surakarta City with 82 unit and South District in the Banjarmasin City with 70 unit. These school number compared with the population size to get the basic rate of school services. Result of the calculation from this early stage served in Table 1.

Table 1. Average Service Rates of Elementary School in Malang, Banjarmasin and Surakarta City

\begin{tabular}{|l|c|c|}
\hline \multicolumn{1}{|c|}{ District } & $\begin{array}{c}\text { Number of School Unit (Only } \\
\text { Within Adm. Boundary) }\end{array}$ & Average Service Rates (\%) \\
\hline Blimbing & 65 & 92.53 \\
\hline Kedungkandang & 77 & 119.29 \\
\hline Klojen & 48 & 94.80 \\
\hline Lowokwaru & 62 & 90.58 \\
\hline Sukun & 71 & 95.16 \\
\hline \multicolumn{1}{|c|}{ Malang City } & $\mathbf{3 2 3}$ & $\mathbf{9 8 . 7 0}$ \\
\hline Banjarsari & 81 & 136.63 \\
\hline Jebres & 54 & 89.62 \\
\hline Laweyan & 53 & 113.61 \\
\hline Pasar Kliwon & 55 & 145.94 \\
\hline Serengan & 32 & 141.14 \\
\hline Surakarta City & $\mathbf{2 7 5}$ & $\mathbf{1 2 2 . 9 0}$ \\
\hline West Banjarmasin & 48 & 88.79 \\
\hline South Banjarmasin & 72 & 111.89 \\
\hline Central Banjarmasin & 40 & 98.55 \\
\hline East Banjarmasin & 43 & 89.86 \\
\hline North Banjarmasin & 49 & 84.20 \\
\hline Banjarmasin City & $\mathbf{2 5 2}$ & $\mathbf{9 5 . 6 7}$ \\
\hline
\end{tabular}

Source: Analysis Results, 2016 

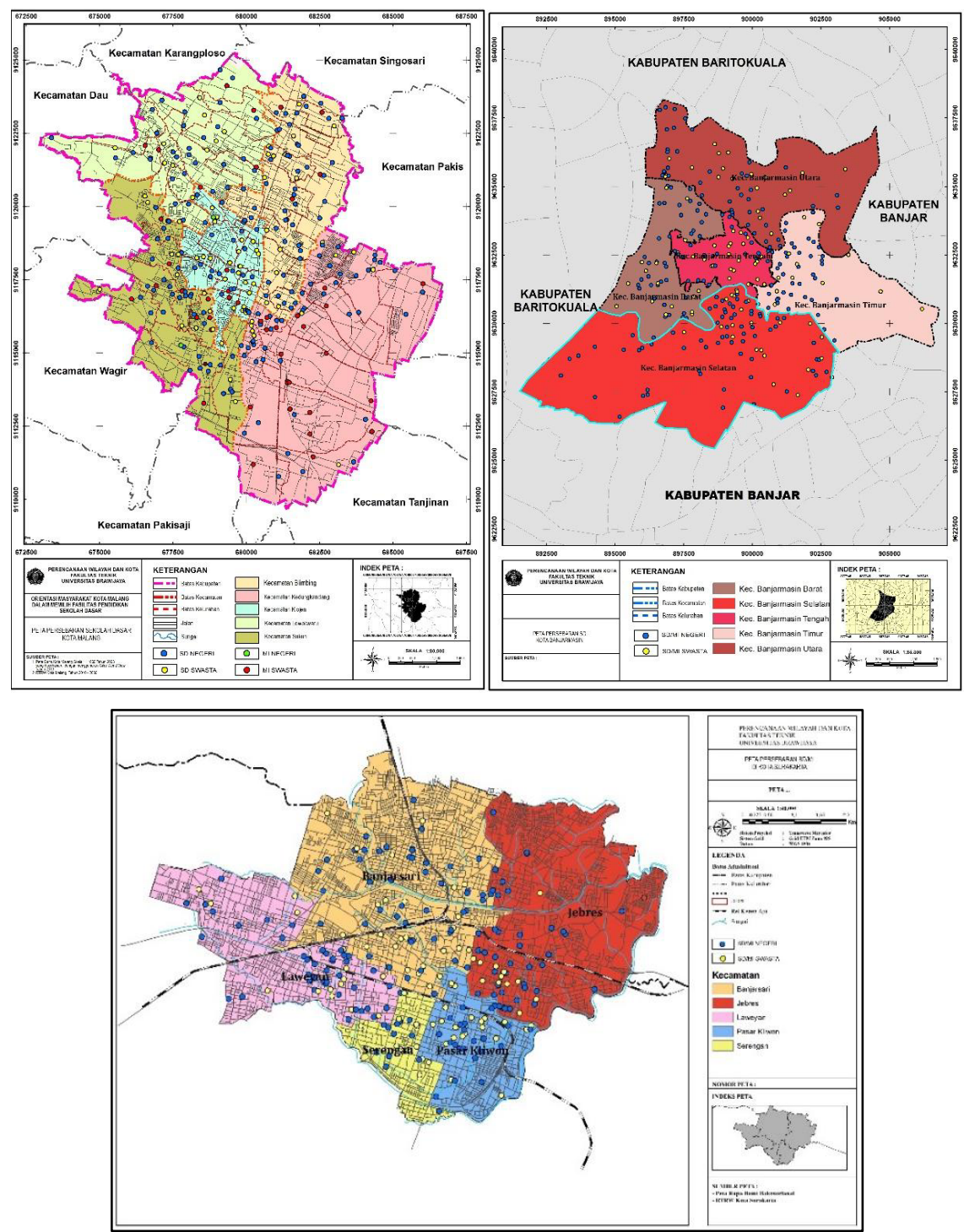

Fig. 2. Map of School Distribution in Malang, Banjarmasin and Surakarta City.

From the result (Table 1), it can be seen that the high average service rates was Surakarta City with $122.90 \%$ when the Malang and Banjarmasin City just has $98.70 \%$ \& $95.67 \%$ respectively. In general, the rate value means elementary school in Surakarta City can meet the needs of facilities solely based on the population size (which can described that the good rate is more than 100\%). And these can not be seen in the Malang and Banjarmasin City which are the service rates just below $100 \%$. In detail, only Kedungkandang District which has high rate of school service reaches $119.29 \%$. This is 
same with Banjarmasin City, which is only South Banjarmasin District has the high school service rates as $111.89 \%$. It is means that elementary school in these district can serves the demand of all population in the district areas. Another districts in Malang and Banjarmasin City has high rates but it still lower than $100 \%$. So it can be indicated that all school in related districts can not meet demand of the population based on simple/basic calculation. In contrast, school in almost all districts in Surakarta City reaches high service rates, except in Jebres District. It means that avalaibility of school in this city can meet the demand of population. From this basic calcution or method shows that there is no specific spatial pattern to define the service rates.

\subsection{Spatial distribution of elementary school by mash/cell catchment (MCC)}

The another method that used in this research is Cell or Mash Catchment Approach which will observe and calculate service rates using grid/cell/mash set system. This method carried out from the conditions that people in the city can choose the elementary school not only near or around their home and they can choose various school in the their city areas. From this conditions, it is indicates that school service not limited by administrative boundaries and the service rates calculate not only facility within the areas but also facility from surrounding areas that can be accessed by people from related areas.

In the first phase, the city area divided by cell or mash set system. Then, the cell or mash set adjusted with land use and derived for the later phase only for cell/mash that contained the built-up area. This method was used to improve the concept of service rates calculation. The next phase is overlay process between school services layer and cell $/ \mathrm{mash}$ set layer in aim to get number of service layers that can be catched in each cell. From this process, it will be known that every cells have different number of school layers and it interpretes that number of school that can be accesses people form those cell. Furthermore to get the final result, the value of each cell within village boundaries will be calculated as mean/average score as whole value for related villages. The result of services scale capacity based by cell or mash method can be seen in map as follows. 


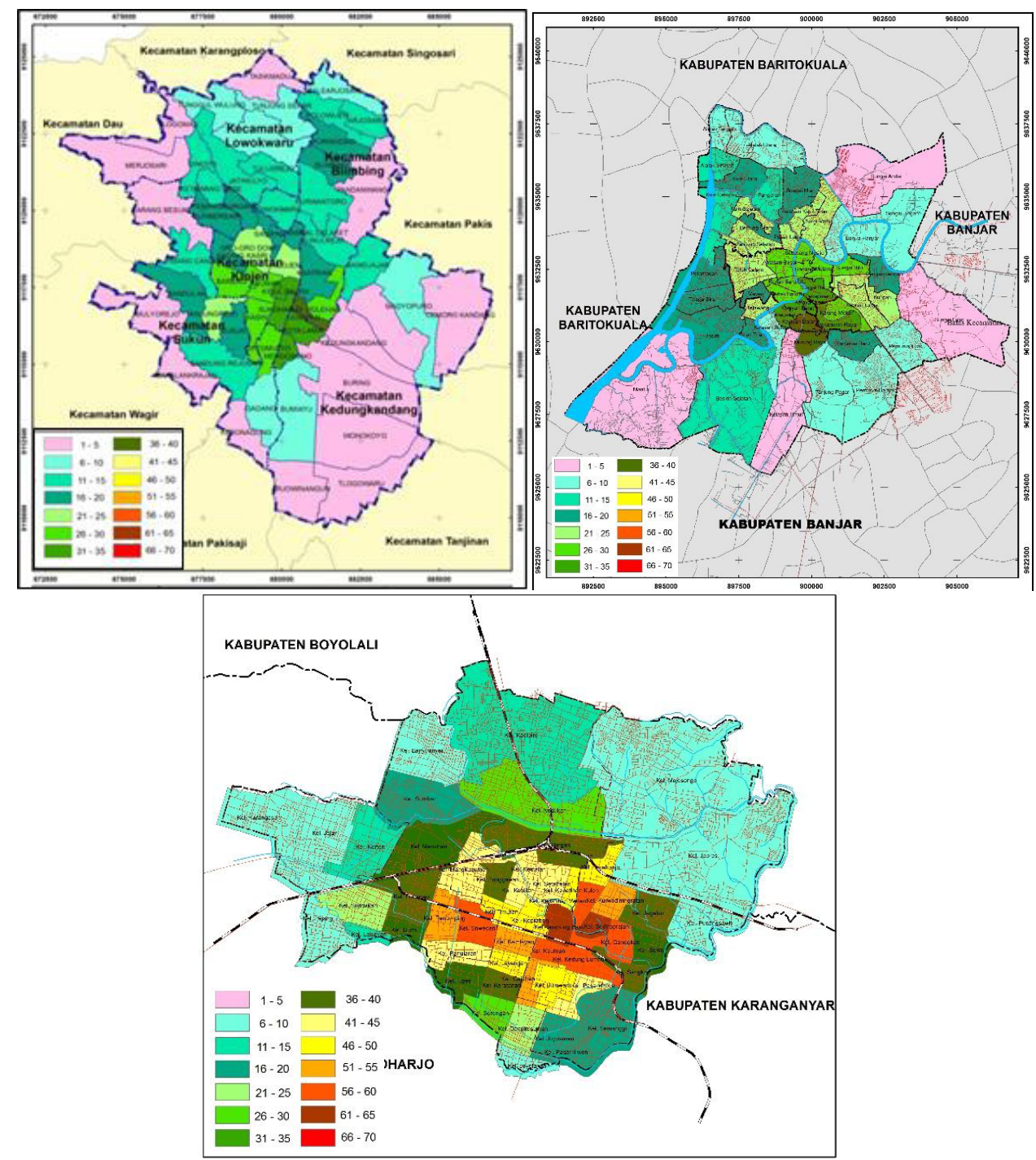

Fig. 3. Map of Elementary School Service Rates based on Mash/Cell Catchment

The mapping results shows number of elementary school that can serves or accessed by peoples in each village. It also can be seen the similarities that area with high value of school service rates in these three cities are villages that are located in the city centre. The highest number of schools that can be accessed by people from each village in Malang and Banjarmasin City was 35 - 40 units. While the Surakarta City has the higher number which are $65-70$ units. It can illustrates that peoples in those villages can access or choose among 40 school freely if they have children in elementary school ages. From the mapping analysis results, it also described that villages in the peripheral or suburban areas has lower 
number of school which average is $1-5$ school units. These results will determine the elementary school service rates in each village. Rates of elementary school service that determine using mash or grid system method can be seen in Table 2.

Table 2. Average Service Rates of Elementary School in Malang, Surakarta and Banjarmasin City Using Mash/Cell/Grid Catchment Method

\begin{tabular}{|l|c|c|}
\hline \multicolumn{1}{|c|}{ District } & $\begin{array}{c}\text { Number of School Units } \\
\text { (Based on Service Layers) }\end{array}$ & Average Service Rates (\%) \\
\hline Blimbing & 175 & 270.48 \\
\hline Kedungkandang & 143 & 187.98 \\
\hline Klojen & 272 & 569.21 \\
\hline Lowokwaru & 122 & 177.65 \\
\hline Sukun & 138 & 169.58 \\
\hline \multicolumn{1}{|c|}{ Malang City } & $\mathbf{8 5 0}$ & $\mathbf{2 7 1 . 7 5}$ \\
\hline Banjarsari & 440 & 1611.40 \\
\hline Jebres & 424 & 1752.63 \\
\hline Laweyan & 300 & 988.67 \\
\hline Pasar Kliwon & 401 & 1896.85 \\
\hline Serengan & 232 & 1265.16 \\
\hline Surakarta City & $\mathbf{1 7 9 7}$ & $\mathbf{1 5 1 0 . 4 0}$ \\
\hline West Banjarmasin & 172 & 336.18 \\
\hline South Banjarmasin & 235 & 468.61 \\
\hline Central Banjarmasin & 336 & 1128.20 \\
\hline East Banjarmasin & 172 & 354.05 \\
\hline North Banjarmasin & 134 & 248.15 \\
\hline Banjarmasin City & $\mathbf{1 0 4 9}$ & $\mathbf{5 3 5 . 6 8}$ \\
\hline
\end{tabular}

Source: Analysis Results, 2016

Based on Table 2, it is known that average school services rates using the mash/cell catchment method has higher than average rates of basic/existing method. The highest average rates located in Surakarta City that reached more than $1.510 \%$. It is means that school in this city can serves 15 times than the demand from existing population. Malang and Banjarmasin City has the lower average service rates which are $271,75 \%$ and $535,68 \%$ respectively. As it said before, areas (districts/villages) that has high rates of school service contentrated in the city centre. Klojen District has the highest service rates in Malang City which is $569,21 \%$; then Pasar Kliwon as centre of Surakarta City and Central Banjarmasin also has the high rates of service which are $1.896,85 \%$ and $1.128,20 \%$ respectively.

These results considered more accurate compared with the basic or esixting method. In addition, the determination of cell/mash/grid in this research considered the land use characteristics in the process of of service rates measurement because it was unbuilt land there is no human activity especially residential activity. Therefore, Moran's I analysis was used to compare the accuracy level of measurement the elementary school service rates in Malang, Surakarta and Banjarmasin City. 


\subsection{Moran's I results}

As it has been discussed, the use of Moran's I analysis is in order to compare the accuracy of the three methods that is measured the elementary school services capacity that has been done before. Moran's I analysis produced Moran's index that gained from spatial weight with GeoDa software. Moran's I analysis chosen because the characteristic of areas affected by activities on those area/characteristics of around so it is also used as a base assumptions in the measurement of elementary education services scale in this city. The measurement of three method that had been done and it obtained Moran index as follows.
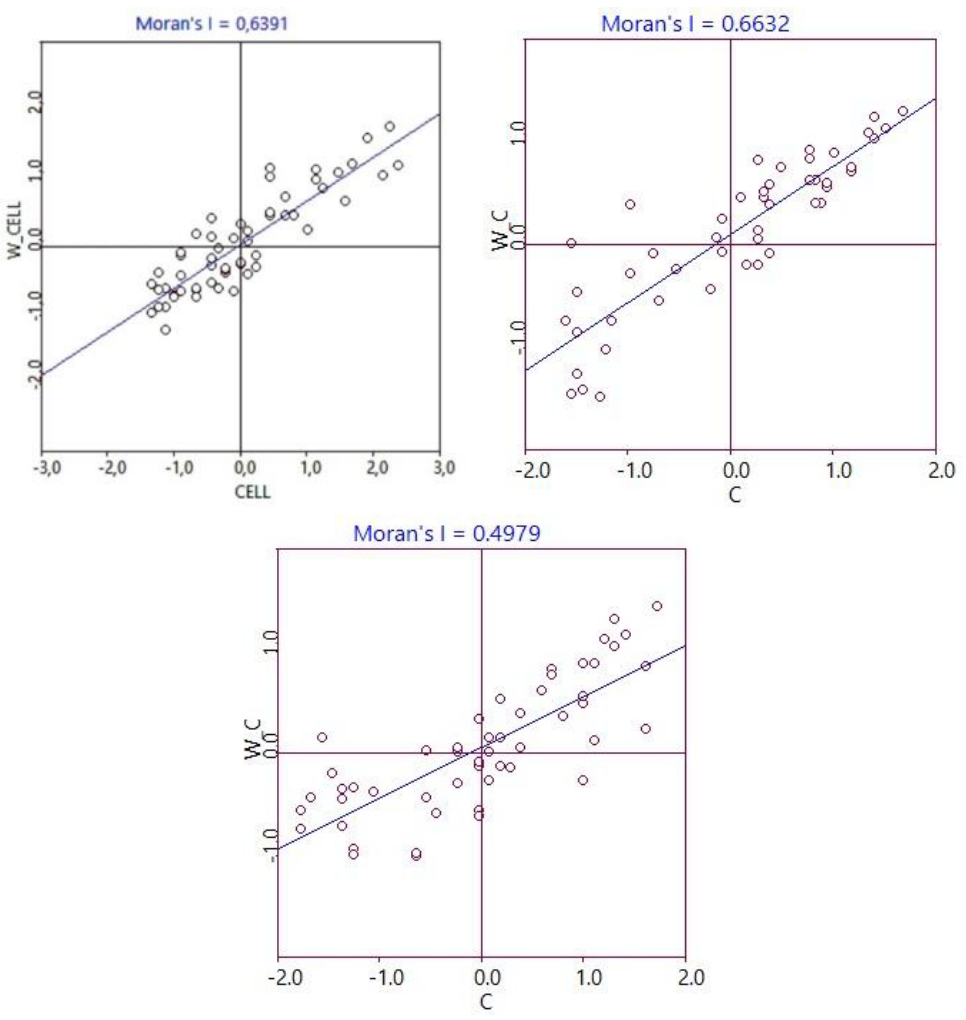

Fig. 4. Moran's I analysis results of service rates in Malang, Surakarta and Banjarmasin City

Based on the results of analysis, it can be seen the value of Moran's I analysis in the Malang and Surakarta City has high correlation index which are 0,6391 and 0,6632 respectively meanwhile Banjarmasin City has average correlation index that is 0,4979 . The index value is indicated that spatial autocorrelation from the object studied is in the category of high correlation. These results strengthened with the LISA Cluster Map (another product of Moran's I analysis). 

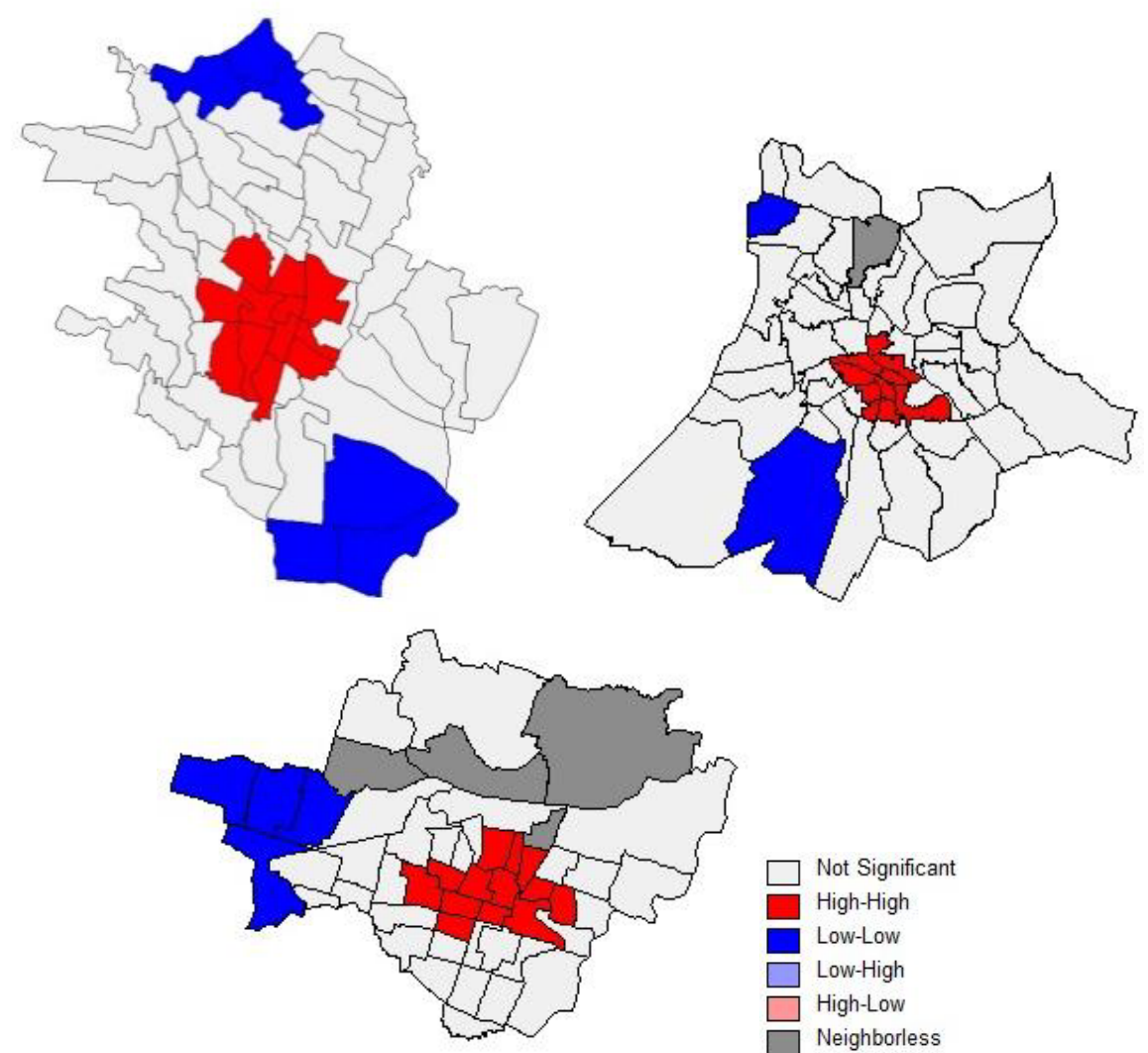

Fig. 5. LISA Cluster map of school service rates in Malang, Surakarta and Banjarmasin City.

Based on the Figure 5, it can be seen that villages in the centre areas has high-high correlation, both in the Malang, Surakarta and Banjarmasin City. These results has relevance with calculation results and it can be described the real condition in the field/city.

\section{Conclusion}

Based on research has been done to determine the method which has accurancy to determine elementary school service rates in Malang, Surakarta and Banjarmasin City using mash or cell or grid system approach. Based on the Moran's I analysis results, it can be said that interaction about access of elementary school is high mainly on urban centers. The result is also able to described the phenomena that happened in the urban areas especially in Indonesia which the parents are freely to choose education facilities for their children ignoring administrative boundaries and it is influenced by the availability of facilities around the city areas. And it is indicates different with rural cases, which is has the lower chance or opportunity to get or access the elementary school or public facility 
freely. Topic about elementary school service pattern in rural areas will conducted in further research.

\section{References}

1 Minister of National Education RI, Minister of National Education RI Policy No. 24, 2007 about Facilities and Infrastructure of Elementary, Junior High Schools and Senior high School Standarts (Republik Indonesia, 2007)

2. National Indonesian Standart 03-1733-2004, The Procedures for Planning a Residential Neighborhood in Urban Areas.

3. R. Puspitasari, I. Susanto, Prosiding of Mathematic and Mathematic Education National Conference (Yogyakarta, 2011)

4. Statistic Agency of Banjarmasin City, Banjarmasin City in Figure 2015 - 2016 (2015)

5. Statistic Agency of Malang City, Malang City in Figure 2015 - 2016 (2015)

6. Statistic Agency of Surakarta City, Surakarta City in Figure 2015 - 2016 (2015) 